\author{
Revue \\ de 'histoire \\ Revue de l'histoire des religions \\ des religions \\ 4| 2011 \\ L'Ordre chrétien médiéval entre le droit et la foi
}

\title{
The Devil at Law in the Middle Ages
}

Le Diable et le droit au Moyen Âge

\section{Karl Shoemaker}

\section{CpenEdition}

Journals

Electronic version

URL: http://journals.openedition.org/rhr/7826

DOI: $10.4000 /$ rhr.7826

ISSN: 2105-2573

\section{Publisher}

Armand Colin

Printed version

Date of publication: 1 December 2011

Number of pages: $567-586$

ISBN: 978-2200-92722-6

ISSN: 0035-1423

\section{Electronic reference}

Karl Shoemaker, "The Devil at Law in the Middle Ages ", Revue de l'histoire des religions [Online],

4 | 2011, Online since 01 December 2014, connection on 01 May 2019. URL : http://

journals.openedition.org/rhr/7826 ; DOI : 10.4000/rhr.7826 


\section{The Devil at Law in the Middle Ages}

By the $12^{\text {th }}$ century, the rise of legal science fostered canonists' and theologians' attempts to define the mystery of divine justice using the rules of procedural law. During the last two centuries of the Middle Ages, this interest was reflected in particular through the dissemination of trial stories (Processus Sathanae) opposing Mary to the devil over the salvation of men. The expression of Marian theology set in juristic terms also confirmed the intrinsic value of Romano-canonical procedure as an institutional foundation of the authority of justice.

\section{Le Diable et le droit au Moyen Âge}

Dès le XII siècle, l'essor de la science juridique romano-canonique nourrit, chez les canonistes comme chez les théologiens, l'ambition de définir le mystère de la justice divine à partir des règles du droit processuel. Dans les deux derniers siècles du Moyen Âge, cet intérêt se traduit notamment par la diffusion de récits de procès (Processus Sathanae) opposant Marie et le diable sur le salut des hommes. Cette traduction de la théologie mariale en termes juridiques confirme aussi la valeur intrinsèque de la procédure romano-canonique comme fondation institutionnelle de l'autorité de la justice. 
"And the Lord said to the demon, "We have founded the laws, and we give to them their authority. The laws do not give authority to us." 1

\section{I/ Canon Law, History, and the Last Judgment}

The propensity for medieval Christian theology to frame history in juridic terms is well known. The confession of faith issued as the first canon (c. Firmiter) of the Fourth Lateran Council in 1215 offers sufficient evidence. It affirmed that at the end of the ages mankind will stand before an omnipotent God who "will judge the living and the dead and will render to each according to his works, the reprobate as well as the elect." 2 The Fourth Lateran Council did not invent this juridic framework for the Christian conception of history, but it emphasized it to such a degree that it became a matter of sustained interest for medieval canonists and theologians alike. The inclusion of the canon Firmiter at the beginning of the Liber Extra, promulgated by Gregory IX in 1234, only reinforced to medieval canonists that there was a seamless relationship between canon law and Christian eschatology. ${ }^{3}$

Although Firmiter was primarily a theological statement, its import for jurists was twofold. First, it used law to divide human history into discrete ages. As the glossa ordinaria to Firmiter elaborated, there are three historical ages, each governed by its own law: the time before law, in which men lived according to the ius naturale; the time under law, which began when God gave the Decalogue to Moses; and the time of grace, which began "when the

1. Processus sathanae contra genus humanum, BnF Lat. 10770, fol. 95d. $\left(14^{\text {th }} \mathrm{C}\right)$.

2. Fourth Lateran Council, c. 1. Constitutiones Concilii quarti Lateranensis una cum Commentariis glossatorum, ed. Antonio García y García (MIC, Series A: Corpus Glossatorum 2; Vatican City, 1981), 1-172. “... iudicaturus vivos et mortuos et redditurus singulis secundum opera sua, tam reprobis quam electis."

3. X 1.1.1 (= 4 Lateran Council c. 1). All citations to the Decretum and the Liber Extra are from the edition of Emile Friedberg, Corpus Iuris Canonici, 2 vols. (Leipzig: Tauchnitz, 1879; reprinted, Graz: Akademische Druck-u. Verlagsanstalt, 1959) unless otherwise noted. 
Son of God taught us the gospels, under which we are ruled today." Second, Firmiter emphasized to medieval canonists that the present age would culminate in the last judgment, a legal process through which a gracious and just God would conclude human history.

That human history would culminate in a legal process was only to be expected. After all, a legal process marked the beginning of human history, which was initiated after Adam and Eve were judged and sentenced to exile from Paradise. In fact, canonists located the inception of their own discipline in that moment. According to Stephen of Tournai, who was borrowing directly from Paucapalea, when Adam was charged with disobedience by God and attempted to claim an "exceptio" by laying a criminal countercharge against Eve, he became a legal actor. "And thus litigating, or what we commonly call the form of pleading, appears to have arisen in Paradise." 5 By finding the origins of their discipline in sacred history, canonists vested canon law with two foundational attributes. First, canonists could claim for canon law a historical priority that competed with theology in the rank of scientiae. ${ }^{6}$ Second, it could be claimed that canon law stood above the three historical ages of law, encompassing, according to Hostiensis, both "the new law and

4. Gl. ord. ad X 1.1.1 iuxta ordinatissimam, "Hec fuit dispositio: quia tria tempora: tempus ante legem, et tempus sub lege, et tempus gratie. In tempore ante legem habebant homines ius naturale, quo regebantur, quod consistebat in his duobus preceptis contentis his versibus: Quod tibi vis fieri, mihi fac: quod non tibi, noli / Sic potes in terris vivere iure poli. Dist. 1 in principio. In tempore sub lege regebantur decalogo Moysi dato a Deo: et tunc contingebat omnia in figura, que completa fuerunt tempore gratie, quondo Dei filius nos docuit precepta evangelica, quibus hodie regimur." Corpus juris canonici emendatum et notis illustratum, 4 vols. (Rome: 1582), vol. 2, col. 9. See, for example, Knut Wolfgang Nörr, "Recht und Religion: über drei Schnittstellen im Recht der mittelalterlichen Kirche," 79 Zeitschrift der Savigny-Stiftung für Rechtsgeschichte (KA) 1-15 (1993).

5. Die Summa des Stephanus Tornacensis, ed. J.F. von Schulte (Giessen: Emil Roth, 1891), "Cum enim Adam de inobedientia argueretur a domino, quasi actioni exceptionem obiiciens relationem criminis in coniugem, immo in coniugis actorem convertit dicens; 'Mulier, quam dedisti mihi sociam, ipsa me decepit et comedi.' Sicque litigandi, vel, ut vulgariter dicamus, placitandi forma in ipso paradiso videtur exorta." Cf. Paucapalea's summa has been printed in Summa über des Decretum Gratiani, ed. Johann Friedrich von Schulte (Giessen: Emil Roth, 1890), p. 1-2; See also Ken Pennington, "Law, Criminal Procedure," Dictionary of the Middle Ages: Supplement 1 (New York: Charles Scribner's Sons-ThompsonGale, 2004: 309-320.

6. See, for example, E. James Long, "Utrum iurista vel theologus plus proficiat ad regimen ecclesiae: A Questio Disputata of Francis Caraccioli," Mediaeval Studies (1968) 30: 134-62. 
the three ages of law." As a result, just as canon law could claim a presence at the beginning of human history, it could also claim a presence at the last judgment, an event whose character as a process of law was not lost on canonists.

The affirmation that Christ would "judge" the living and the dead at the end of the ages also elided an alternative possibility, contemplated but rejected by medieval theologians, in which the redemption of mankind from original sin and servitude to the devil might be accomplished through a simple exercise of divine power rather than judgment. The possibility that human salvation might harbor a contradiction between the justice and power of God had been recognized in the doctrines of the ancient Church. For example, St. Augustine had contemplated a tension between divine power and justice in his treatise De trinitate, but stressed that it "pleased God" to free man from the devil by justice rather than power. ${ }^{8}$ Nonetheless, insistence on the priority of divine justice over divine power preserved a tension with which medieval theologians continued to grapple. In the early twelfth century, the problem was posed in the following manner:

Did not the devil do an injury to God whose servant he first fraudulently deceived and afterward violently held? Therefore, what injustice would God commit if he wrested man from the hands of the unjust invader with only a word of his power? ${ }^{9}$

Although the anonymous author (long, but incorrectly, thought to be Hugh of Saint-Victor) seemed to be inviting the conclusion that nothing prevented God from exercising his power at the expense of his justice, he was deeply anxious to preserve the role of divine justice in the redemption of mankind from the power of the devil. The same text later offered an even sharper formulation of the

7. Hostiensis, Summa Aurea, Proemium, num. 41 (Lyon: 1537).

8. De trinitate, Patrologia Latina (Hereafter PL), ed. J.-P. Migne (Paris) 42: 1027 "Placuit Deo, ut propter eruendum hominem de diaboli potestate, non potentia diabolus, justicia vinceretur."

9. PL 175: 617 Quaestiones in Epistolas Pauli, "Sed nonne diabolus injuriam Deo fecerat, qui servum prius fraudulenter decepit, et post violenter possedit? Quam ergo iustitiam faceret Deus, si solo verbo potentiae suae eriperet hominem de manu injustissimi invasoris ?" Patrice Sicard has demonstrated that this text was not authored by Hugh of Saint-Victor. See Hugues de Saint-Victor et son école: introduction, choix de texte, traduction et commentaires (Turnhout: Brepols, 1991) pp. 273-277. 
problem: "This is the justice by which Christ vanquished the devil. The devil is a lover of power, and a forsaker of justice... Christ was unwilling to use power against a lover of power, but wanted to use justice against a forsaker of justice." Thus, we should act in the same way toward our enemies so that "not by power, but rather through justice we will be victors." 10

This anonymous text echoed some of the central tenets of the ancient dogma known as the ransom theory of salvation, which credited the devil with obtaining a proprietary right in humankind at the moment of original sin. ${ }^{11}$ Hence, the emphasis placed on the justice of Christ stemmed in part from an anxiety that the devil possessed rights in humankind which would have been unjustly violated if Christ accomplished the liberation of mankind from the devil by an act of raw power. Such anxieties persisted despite the fact that Anselm of Canterbury, writing in the late eleventh century, is generally credited with negating the idea of the devil's rights, at least as a theological matter. By denying that the devil had any rights, Anselm had relaxed the tension between the power and justice of God by collapsing the distinction between them. "In an evil angel there can be no justice at all. There was no reason, therefore, in respect to the devil, why God should not use his own power against him for the liberation of mankind."12 Anselm's solution was to show that in employing his power against the devil, God acted justly against one who did not deserve justice. But Anselm's demonstration that the devil had no legal claim on humankind left intact the question as to whether the salvation of humankind was an expression of God's justice or his power, and this question

10. $P L$ 175: 466, "Haec est justitia, qua Christus vicit diabolum. Diabolus amator potentiae, et desertor justitiae, Christum, in quo nihil dignum morte invenit, occidit... Noluit itaque contra amatorem potentiae uti potentia, sed contra desertorem justitiae voluit uti justitia, ut non informaret qualiter contra eumdem hostem nobis sit pugnandum; videlicet non potentia, sed potius justitia, et sic victores erimus."

11. A succinct statement of this doctrine and its power is given in R.W. Southern, Saint Anselm: A Portrait in a Landscape (New York: Cambridge University Press, 1995) pp. 207-211; criticism of Southern's account of the reception of Anselm's theory in medieval Christianity can be found in C.W. Marx, The Devil's Rights and the Redemption in the Literature of Medieval England (Cambridge: Cambridge University Press, 1995).

12. Cur Deus Homo, 1.7. See, generally, Jaroslav Pelikan, The Growth of Medieval Theology: 600-1300, (Chicago: The University of Chicago Press, 1978), pp. 108-118. 
continued to trouble theologians in subsequent centuries. By the thirteenth century, however, the problem of divine justice was also increasingly a matter of concern for canonists. Examination of this question requires first assessing the disciplinary differences that had come to divide theologians and canonists in the late-medieval period before examining a fourteenth-century canon law manuscript which offers a unique approach to the problem of divine justice.

\section{II/ Tensions Between Canonists and Theologians}

If medieval canonists and theologians were ostensibly concerned with the same problem - namely, the nature and contours of God's justice within the dogma of Christianity - they approached it from disciplinary perspectives that were increasingly antagonistic toward one another. Historians of medieval canon law have rightfully stressed its insularity and autonomy - tracing "a process of emancipation" from theology that was begun in the twelfth century and picked up momentum thereafter. ${ }^{13}$

Indeed, discord between canonists and theologians regarding their respective roles within the mystical body can be detected early on. In a famous passage of De consideratione, composed around 1148, Bernard of Clairvaux asked his former student, the recently enthroned Pope Eugene III (1145-53):

Therefore, when do we pray? When do we teach the people? When do we edify the Church? When do we meditate on the Law? However, everyday in the [papal] palace they make such a noise of the laws, but of Justinian, not of the Lord. ${ }^{14}$

Bernard of Clairvaux's remark highlighted the pious understanding of "Law" claimed by twelfth-century theologians

13. The phrase is from G.H.M. Posthumus Myejes, "Exponents of Sovereignty: Canonists as Seen by Theologians in the Late Middle Ages," in The Church and Sovereignty c.590-1918. Essays in Honour of Michael Wilks (Blackwell, Oxford, 1991), at p. 302.

14. De consideratione 1.4 in Opera, eds. J. Leclercq and H.M. Rochais (Rome, 1963), vol. 3, p. 399 [PL 182: 732-3] "Denique quando oramus? quando docemus populos? quando aedificamus Ecclesiam? quando meditamur in lege ? Et quidem quotidie perstrepunt in palatio leges, sed Justiniani, non Domini... Nam certe lex Domini immaculata, convertens animas. Hae autem non tam leges, quam lites sunt et cavillationes, subvertentes judicium. Tu ergo pastor et episcopus animarum, qua mente, obsecro, sustines coram te semper silere illam, garrire istas?" 
and denigrated the crass understanding of "laws" attributed to canon lawyers, whom Bernard thought corrupted the Church with the laws of ancient emperors. In Bernard's view, the "Lex domini immaculata" had the capacity to convert souls, while the leges preoccupying canonists, which "are not so much laws as strife and scoffing, subvert[ed] judgment." 15 Bernard marveled that the pope, "a pastor and bishop of souls," could tolerate the lawyers and their accompanying litigious prattle that beset him daily. ${ }^{16}$ In the eyes of the theologians, the canonists' preoccupation with litigiousness and the legislation of Roman emperors was inconsistent with meditation on divine justice.

The opprobrium theologians heaped upon canon law seems to have appeared simultaneously with the growth of the new universities, which, by the early thirteenth century, had dedicated faculties for the study of canon law. ${ }^{17}$ Indeed, the study of canon law thrived, emerging from a "proto-professional" period, which James Brundage has located between 1150 and 1190, into a full-blown profession in the thirteenth century. ${ }^{18}$ By the late twelfth century and thereafter canon law had reached a stage of development in which elite practitioners could dedicate their working lives to its practice and scholarship. Canon lawyers in this era typically earned university degrees in law, sometimes in both canon and civil law, and the successful ones could look forward to a relatively structured career path that included university study, a period of teaching,

15. Id. The phrase "lex Domini immaculata" is a reference to Psalms 18:8.

16. Id. "Tu ergo, pastor et episcopus animarum, qua mente, obsecro, sustines coram tu semper silere illam, garrire istas ?"

17. Yves M.-J. Congar, "Un témoignage des désaccords entre canonistes et théologiens," in Études d'histoire du droit canonique: dédiées à Gabriel le Bras, 2 vols. (Paris, 1965) pp. 861-84; Joseph de Ghellinck, "Magister Vacarius; Un juriste théologien peu aimable pour les canonistes." Revue d'histoire de l'Église de France (1943) 44: 173-78. Alan B. Cobban, "Theology and Law in the Medieval Colleges of Oxford and Cambridge", Bulletin of the John Rylands Library of Manchester, 65 (1982), pp. 57-77; See D. N. Lepine, "The Origins and Careers of the Canons of Exeter Cathedral, 1300-1455," in Religious Belief and Ecclesiastical Careers in Late Medieval England: The Proceedings of the Conference Held at Strawberry Hill, Easter, 1989, ed. C. Harper-Bill (Woodbridge, Suffolk, Boydell Press, 1991), pp. 87-120.

18. James Brundage, "The Rise of Professional Canonists and the Development of the Ius Commune," Zeitschrift der Savigny-Stiftung für Rechtsgeschichte (KA) (1995) 81: 26-63, at 31; Colin Morris, "From Synod to Consistory: The Bishops' Courts in England, 1150-1250," Journal of Ecclesiastical History (1971) 22: $115-23$. 
service as an advocate or counselor and, perhaps, an appointment in ecclesiastical administration. ${ }^{19}$

It is possible, of course, to exaggerate the differences between canonists and theologians. They still shared much in common. For example, Hostiensis, one of the most esteemed canonists of the thirteenth century and a cardinal, also wrote a short theological treatise on the Credo. ${ }^{20}$ Furthermore, theologians and canonists collaborated in the heresy controversies that emerged under the pontificate of John XXII in the early fourteenth century. ${ }^{21}$ Nonetheless, such involvement by canonists tended to antagonize the theologians. ${ }^{22}$ It did not help matters when Hostiensis (as reported by his critic, the theologian Pierre D'Ailly) claimed that:

Canon law indeed can be called the science of sciences. For if it is well understood, through it the temporal as well as the spiritual [realms] can be ruled. ${ }^{23}$

The theologians understood immediately that the descriptive "scientia scientiarum" was a purposeful elevation by Hostiensis of canon law above theology within the scholastic hierarchy of knowledge. Despite the hubris he displayed, Hostiensis could claim legal authority for his assertion. Justinian's Digest had called jurists and judges "priests of justice" because they "worship justice and profess the knowledge of what is good and fair." ${ }^{24}$ Medieval jurists (both Romanists and canonists) did not fail to elaborate on this association. ${ }^{25}$ For example, Accursius understood the priesthood of jurists to mean that those wanting to become lawyers did not

19. Brundage, "The Rise of Professional Canonists," 44-5.

20. Jean Longère, "L'enseignement du Credo: conciles, synodes et canonistes médiévaux jusqu'au XIII siècle," Sacris Erudiri (1991) 32: 309-341.

21. Alain Boureau, Satan hérétique. Naissance de la démonologie dans l'Occident médiéval (1280-1330) (Paris, Odile Jacob, 2004).

22. I elaborate on these issues in an article dedicated to my colleague William J. Courtenay. See Karl Shoemaker, "When the Devil Went to Law School" in Crossing Boundaries, ed. Spencer Young (New York: Brill, forthcoming 2011).

23. D'Ailly, Utrum indoctus in iure divino possit iusta praeesse in Gersoni Opera Omnia, 5 vols. (Antwerp, 1706) 5: 655 a-b. "Haec scientia vere potest scientia scientiarum nuncupari. Nam si bene intelligatur, per eam tam temporalia quam spiritualia regi possunt." D'Ailly appears to have been paraphrasing some remarks of Hostiensis in the Proemium to his Summa Aurea.

24. D. 1.1.1. See also Ulrich von Lübtow, "De iustitia et iure," Zeitschrift der Savigny-Stiftung für Rechtsgeschichte (RA) (1948) 66: 458-465.

25. Ernst Kantorowicz, The King's Two Bodies: A Study in Mediaeval Political Theology (Princeton University Press, 1957), 120-1. 
need to study theology, because theology is already found within the law. ${ }^{26}$ The tractatus de legibus in Gratian's Decretum had also taught canon lawyers that their discipline required knowledge of human laws and divine law, and invited the inference, contested strenuously by theologians like Ockham, that mastery of canon law encompassed mastery of theology as well. ${ }^{27}$

For medieval canonists, the distance between the claim that they had special province in matters concerning the governance of this world as well as matters governing entry into the next world was not all that great. When the Fourth Lateran Council asserted that Christ would "render to each according to his works," the canonists surely heard an echo of Ulpian's famous definition of justice as the "constant and perpetual will to render to each according to his right." 28 The centrality of divine justice in the economy of salvation also raised other associations for medieval canonists, who would have taken to heart the juridical implications of the Pauline language of salvation as a "justification." 29 From this perspective, the pretensions of the canonists begin to take a different shape. Canon law, they could claim, was not merely the specialized, but subservient, knowledge necessary for ordering the processes by which the Church was administered on earth. It also entailed the knowledge of justitia, understood both as an attribute of divinity and as "the state of man 'justified' before God."

But of course divine justice is not limited to humankind. Satan and his demons are its objects as well. It may have been considerations such as these that lay behind William Durantis' quip that even the devil would receive legal process if he asked for his case to be

26. Glossa ordinaria ad Dig. 1.1.10 "Sed numquid secundum hoc oportet quod quicumque vult iurisprudens vel iurisconsultus esse, debeat theologiam legere? Respondeo, non; nam omnia in corpore iuris inveniuntur."

27. Decretum, D. 21 , c. 1. "Nam maiorum haec erat consuetudo, ut rex esset etiam sacerdos et pontifex. Unde et Romani Imperatores pontifices dicebantur." This was a passage that the civilian jurists, such as Azo, did not overlook. See Ernst Kantorowicz, The King's Two Bodies, p. $125 \mathrm{ff}$.

28. Dig. 1.1.10.

29. See, above all, Stephan Kuttner, "A Forgotten Definition of Justice," Mélanges Gérard Fransen (Studia Gratiana 20; Rome, 1976) 76-110, reprinted in Kuttner, The History of Ideas and Doctrines of Canon Law in the Middle Ages (London, 1980) 75-109.

30. Id. at 78 . 
heard. ${ }^{31}$ It may also have been these considerations that prompted late-medieval canonists to pay considerable attention to the devil and his relationship to justice. In the preface to his Summa, Rufinus explicitly cast the devil as an enemy of humankind and justice:

The dignity of the human creature before sin emanated from these two things, as if suspended from cords, namely, the rectitude of justice and the clarity of knowledge. By the former it presided over human matters and through the latter it drew near to heavenly matters. But as the envy of the devil increased, the rectitude of justice was pushed down by the weight of perverted malice and the light of knowledge was obscured by the gloom of error. ${ }^{32}$

Fourteenth-century canonists continued to display a keen interest in the devil, typically focusing on his role as an accuser of mankind. The ordinary gloss to the Liber Extra noted the prosecutorial character of the devil, and offered the following creative etymology:

The devil is called "incriminator" and it is a Greek word. It is derived from "dia," that is, "two," and "bolus," that is "a little morsel," because he seeks to make two little morsels of the body and the soul. ${ }^{33}$

Albericus de Rosate's fourteenth-century legal dictionary contained several entries under diabolus as well as daemones, entries which stressed not only the accusatory role of the fallen angels, but also their insightful understanding of human nature and human laws. ${ }^{34}$ The glossators also took notice of demonology. In his gloss on the Liber Extra, Johannes Andreae included a fanciful explanation that the word "daemones" was formed from

31. Speculum iuris (Basel: 1574) de inquisitione (p. 42): "et etiam diabolo, si in iudicio adesset, non negaretur." See also, Ken Pennington "Due Process, Community, and the Prince in the Evolution of the Ordo iudiciarius," Revista internazionale di diritto comune (1998) 9:9-47.

32. Die Summa Magistri Rufini, ed. F. von Schulte (Giessen: Emil Roth, 1892), p. 2. See also Robert Sommerville and Bruce Brasington, Prefaces to Canon Law in Latin Christianity: Selected Translation, 500-1245 (New Haven: Yale University, 1998), p. 191.

33. "Diabolus: Dicitur criminator, et est graecum vocabulum, derivatur autem a dia, quod est duo, et bolus, quod est morsellus, quia duos bolos tantum de corpore et anima quaerit facere." Corpus juris canonici emendatum et notis illustratum, 4 vols. (Rome: 1582), vol. 2, col. 8.

34. Albericus de Rosate, Dictionarium iuris tam civilis, quam canonici (Venice 1573). Most of the pertinent entries were distillations of the attributes of demons that Thomas Aquinas had given in his De demonibus (Rome, 1982) 23: 279-334. 
"deorsum," since demons have a will to do what their name says, "to cast down." ${ }^{35}$ Despite their destructive power, and their intimate knowledge of law, the devil and his demons were fundamentally characterized by their lack of faith. ${ }^{36}$ This lack of faith, taught canon law, rendered demons unable to properly understand law and justice. On this point, the theologians and the canonists were in fact not very far apart. Still, it would be within the province of canon law that the question of the justice due to the devil was cast in the form of a lawsuit between Mary and the devil.

\section{III/ The Processus SathanaE}

It may be that the close attention that fourteenth-century canonists paid to the devil and his demons was a result of the generally increased interest in demonology that historians have noted emerging at the end of the thirteenth century. As Alain Boureau has recently argued, a juridification of demonology appears to have occurred during the papacy of John XXII, generating specialized interest in demons among theologians and canonists alike. ${ }^{37}$

A fascinating consequence of this juridical interest in the legal standing of the devil was the production of an anonymous manuscript tradition, sometimes known under the rubric Processus Sathanae, that emerged in the first third of the fourteenth century. The Processus Sathanae was simultaneously an account of human salvation told from within the framework of Roman-canon law and a demonstration of how the devil's lack of faith was fatal to his ability to fully understand the justice he so strenuously sought.

The premise of the Processus Sathanae was that the devil and his hellish council selected a demon learned in the law and sent him to the court of heaven in order to sue for a legal title to the human race. The Virgin Mary, who eventually served as the legal

35. Johannes Andreae, In Quinque Decretalium Libros Novella Commentaria (Torino: Bottega d'Erasmo, 1963), fol. 9, “daemon vel deorsum fluens, vel ruens, ut quod habet in voluntate, ferat in nomine: nonnullus qui decidit, sursum ascendere monet: sed deorsum ruere suadet, unde Matt. 4, 'si filius Dei es, mitte te deorsum."”

36. Johannes Andreae, In Quinque Decretalium Libros Novella Commentaria (Torino: Bottega d'Erasmo, 1963), fol. 6.

37. Alain Boureau, Satan hérétique, op. cit. 
representative for the human race in the suit, and the demon, who served as Hell's advocate, engaged in sophisticated and detailed legal arguments over the ultimate fate of humanity. Both advocates relied heavily on Roman and canon law authorities, though at certain points the Bible was also cited. Christ served as judge in the case.

Scholars have long recognized that the basic narrative structure of the lawsuit was lifted directly from the Maskeroen chapter of Jacob van Maerlant's late thirteenth-century Dutch text Boek van Merline (c. 1260), which in turn had borrowed liberally from Robert de Boron's slightly earlier Merlin. ${ }^{38}$ In these texts, which belonged to the Arthurian literary tradition, the devil's lawsuit was presented as Hell's response to the harrowing accomplished by Christ after his crucifixion and before his resurrection, in which the Old Testament elect were forcibly liberated from captivity in Hell. Van Maerlant's text circulated widely, and was even translated into other vernacular languages.$^{39}$ At some point early in the fourteenth century, however, an unknown person rendered van Maerlant's text into Latin, set it within the procedural framework required by Roman-canon law, and supplied the various legal and theological assertions within the text with citations of relevant legal authorities. The citations inserted into the trial narrative are of uneven reliability, and may have been part of student exercises at Bologna. ${ }^{40}$ Copies of the lawsuit also circulated widely, identifiable in at least two distinct manuscript

38. See J.P. Wickersham Crawford, "The Catalon Mascaron and an Episode in Jacob van Maerlant's Merlijn," Publications of the Modern Language Association (1911) 26: 31-50; Merlin: A Case Book, eds. Peter Goodrich and Raymond H. Thompson (Routledge, 2003), pp. 1-104; Jacob von Maerlant, Historie van den Grale und Boek van Merline, ed. Timothy Sodmann (1980).

39. Willem Gerritsen, "Jacob Van Maerlant and Geoffrey of Monmouth," in An Arthurian Tapestry: Essays in Memory of Lewis Thorpe (Glasgow, 1981) 368388. Representations of Mary or Christ engaged in a dispute or lawsuit with the devil were immensely popular, and many vernacular versions appeared in the late Middle Ages. See, e.g., Frederick Roediger, Contrasti Antichi: Christo e Satana (Florence, 1887); L'Advocacie Notre-Dame, ou La Vierge Marie plaidant contre le diable (Paris, 1855); "Mascarón" in Colección de Documentos inéditos del Archivo general de la Corona de Aragón, eds. D. Próspero de Bofarull y Mascaró, vol. 13. (1853).

40. Biblioteca di Collegio di Spagna, ms. 126, fol. 189r-195r. This manuscript shows clear evidence of the insertion of citations (allegationes) into the text of the lawsuit. 
recensions, and were printed several times in the late-fifteenth and early-sixteenth centuries.

Surprisingly, only scant legal-historical attention has been paid to this record of the devil's litigiousness. The text is not altogether unknown to scholars, but it has not been closely studied. Earlier generations of legal historians, including such luminaries as Friedrich Karl von Savigny (1779-1861) and Sir Paul Vinogradoff (1854-1925), mentioned various versions of the lawsuit between Mary and the devil in their surveys of medieval legal literature, but dismissed them as curiosities. Savigny found the depiction of sacred subjects frivolous, bordering on sacrilege; Vinogradoff simply found the text "curious." 41 J. Neville Figgis considered the text a "jeu d'esprit," but was rather dismissive of it. ${ }^{42}$ Even scholars who refused to dismiss the text as a mere bad joke or sacrilege asserted that it belonged more properly to the antiquarian study of the "dogmatic tradition of the ancient Church" rather than to the study of medieval canon law or theology proper. ${ }^{43}$ The unlikely possibility that Bartolus, the great fourteenth-century jurist, had actually composed one version of the devil's lawsuit prompted occasional but unsustained interest from legal historians. ${ }^{44}$ On

41. Friedrich Von Savigny, Geschichte des Römischen Rechts im Mittelalter. Bd. 6. Das vierzehnte und fünfzehnte Jahrhundert. (Heidelberg, 1831), p. 160. "Der Rechstreit zwischen der Jungfrau Maria und Teufel betrifft das Heil des Menschengeschlechts, und soll dazu dienen, den ganzen Gang des Prozesses an einem erdichteten Beyspiel anschaulich zu machen. In der That aber erscheint diese Arbeit, den Frevel an heiligen Gegenständen ungerechnet, als ein pedantischer, breit durchgeführter Spass." Paul Vinogradoff, Roman Law in Medieval Europe ( ${ }^{\text {nd }}$ ed, Oxford, 1929) p. 129-30, though he appears to have confused the Processus Sathanae and the slightly later Belial tradition. On the Belial tradition, see Norbert Ott, Rechtspraxis und Heilsgeschichte: zu Überieferung, Ikonographie, und Gebrauchssituation des deutschen Belial (Munich, 1983).

42. J. Neville Figgis, "Bartolus and the Development of European Political Ideas," in Transactions of the Royal Historical Society, New Series, Vol. 19, (1905), pp. 147-168, at p. 164.

43. Roderich Stintzing, Geschichte der populären Literatur des römischkanonischen Rechts in Deutschland am Ende des fünfzehnten und im Anfang des sechszehnten Jahrhunderts, (Leipzig, 1867).

44. The difficulties with attributing the text to Bartolus are shown in Carmen Cardelle de Hartmann, "Satan vor Gericht: Die Processus Satanae als Inszenierung juristischer Rhetorik," in Die antike Rhetorik in der europäischen Geistesgeschichte, eds. Wolfgang Kofler and Karlheinz Töchterle (Wien: 2002). De Hartmann gives a description of the various manuscripts which follows Stintzing (see note above). For the view that Bartolus authored the Processus Sathanae, see Robert Jacquin, "Le Procès de Satan," in Bartolo da Sassoferato: Studi e 
balance, however, the Processus Sathanae has received surprisingly little scholarly attention.

We first meet the demonic procurator as he approached the heavenly throne and exclaimed: "I am a damned procurator for iniquitous Hell appearing before you in order to bring an action against humankind." ${ }^{45}$ Christ responded in an unwelcoming manner: "We are not willing to be informed by you, for we recall how while we were walking on the earth you wished to inform us. You said, 'speak, so that these stones become bread' and you said you would give us riches if we worshipped you." ${ }^{46}$ But the demon insisted, making it explicit that he expected his lawsuit to be heard. "You are justice and truth. I am seeking justice, petitioning that humankind be called before you on a certain day in order to respond to me, the procurator of iniquitous Hell." ${ }^{47}$ The demon then presented his procuratorium, which validated his right to speak on behalf of Hell, noting, "without this I should not be admitted." ${ }^{48}$ After inspecting the writ and finding it free of calumny, Christ permitted the demon to proceed. The demon began by requesting a day to be assigned upon

documenti per VI centenario, (2 vols.) (Milan, 1962); Jacquin's view appears to be partially adopted by Scott L. Taylor in "Reason, Rhetoric, and Redemption: The Teaching of Law and the Planctus Mariae in the Late Middle Ages," in Medieval Education, eds. Ronald B. Begley and Joseph W. Koterski, S.J. (Fordham, 2005) 68-81. Nonetheless, perhaps because a version of the Processus Sathanae appears in a Bolognese manuscript that contains a number of Bartolus' texts (as well as some consilia of Baldus de Ubaldis), the association was an easy one for early printers to make.

45. For all that follows, I rely on the manuscript BnF lat. 10770 (f. $189 \mathrm{v}-195 \mathrm{v}$ ) (c. 1360). Other copies of the manuscripts are BnF lat. 18216, Vatican Ross. lat. 1124 (129r-135r), as well as those catalogued by de Hartmann in "Satan vor Gericht: Die Processus Satanae als Inszenierung juristischer Rhetorik," in Die antike Rhetorik in der europäischen Geistesgeschichte, eds. Wolfgang Kofler and Karlheinz Töchterle (Wien: 2002) and Ina Friedlaender, "Processus Satanae Contra Genus Humanum: Ein Förbisedd Litterär Text I En Formulärbok Från Vadstena Kloster," Archivistica et Mediaevistica Ernesto Nygren Oblata (Stockholm, 1956), pp. 123-157. A printed edition of the text, dubiously attributed to Bartolus, is the Tractatus Iudiciorum: Processus Sathanae contra genus humanum (Johan Petit, Paris, 1510).

I am currently at work on a monograph that examines the historical, legal and theological contexts of the text, as well as editions of the text in its two prominent variations.

46. Fol. 189v. Christ is making references to the temptation he suffered at the hands of the devil in the desert.

47. Ibid.

48. Ibid. 
which humankind should appear and asked that humankind appear "tomorrow." To this, Christ replied, "You know from experience that the way [here] is long. We are not in agreement, and thus the judge is to assign the day. Thus, we assign you a day, namely Good Friday, the day I hung upon the cross and died." 49

Anticipating that this did not bode favorably for the outcome of his case, the demon objected, saying "Lord, everywhere this day is celebrated." ${ }^{50}$ Arguing that even the divine law forbade assigning a court day on a holy day, the demon claimed that no binding judgment could be issued on Good Friday. Christ answered thus, "We have founded the laws and we give to them authority. They do not give authority to us."

Medieval jurists would have recognized the political resonance of this statement, for it held implications for both royal and papal politics. For example, Bracton, the most well-known commentator on English common law in the thirteenth century, read the cosmic conflict between Christ and the devil as an argument for the submission of earthly kings to earthly law. ${ }^{52}$ And as William Courtenay has shown, some canon lawyers even transplanted the theological language of divine power (potentia absoluta and potentia ordinata) to the realm of papal power and attributed to the pope the power to act outside the process of law. ${ }^{53}$ In fact, some canonists held the view that the pope, like God, was only bound by the law by his own benevolence, not necessity. ${ }^{54}$ Hostiensis, for example, argued that the pope could suspend the ordinary operation of the law on account of ratio status ecclesiae. Whether or not canonists thought that the pope could claim this divine power (and some thought he could), Christ as judge was asserting an unqualified power to circumvent the rules of legal process. The problem of the relationship between divine justice and divine power had been recast as a matter of judicial prerogative.

49. Ibid.

50. Ibid.

51. Ibid.

52. See Bracton, De legibus f. 5b, 2:33; and the discussion by Kantorowicz, The King's Two Bodies, p. 156.

53. William J. Courtenay, Capacity and Volition (1990), p. 93-94.

54. Hostiensis, Lectura in quinque decretalium Gregorianarum libros, ad 5.31 .8 (Venice, 1581). 
Hence, Good Friday was designated as the day for humankind to appear and the lawsuit to proceed, and the Archangel Gabriel was commanded to summon humankind.

On the appointed day, the demon returned to the court of heaven and waited impatiently to be heard. No one appeared on behalf of humankind and the demon eagerly requested letters establishing the failure of humankind to appear. Christ refused the request of the demon, instead ruling that humankind should be given an extra day to appear. This caused the demon to exclaim, "Where is justice? I do not find it in heaven!" 55

At this point, we learn that the Virgin Mary had been following all these events and was resolved to serve as an advocate on behalf of humankind ${ }^{56}$ Realizing that Mary intended to serve as an advocate for humankind, the demon cried out, "Holy Father, let not flesh and blood move you!" 57 The demon then made two objections in law. First, he explained, Mary cannot be an advocate because she is a woman. Second, she is the mother of the judge..$^{58}$

The Virgin Mary was ready with a response. Although it is true that "women generally are not admitted to the office of advocate," she explained, women are permitted to serve as advocates for orphans, widows, and miserable persons. Since many such persons would be returned to servitude in hell if no one spoke on behalf of humankind, she should be allowed to stand as an advocate notwithstanding the fact that she was a woman. Moreover, Mary explained, if she were an excommunicant, she would be able to act as advocate for herself. And although she was the mother of the judge, she was also a member of humankind and thus named defendant in the lawsuit. In fact, not only did Mary belong to humankind, she was simultaneously a member of all three orders of women: married, chaste, and a virgin. As such, she had the right to serve as an advocate despite her sex and her relation to the judge.

Displeased, the demon had no choice but to proceed. Initially, the demon cast the case as one of spoliation. Hell and its demons had been in "peaceful possession" of humankind for thousands of years without any objections being made, but were recently

55. Fol. 190r.

56. Fol. 190v-191r.

57. Fol. 191r.

58. Fol. 191r-191v 
unjustly dispossessed. Therefore, the demon demanded immediate and full restitution. ${ }^{59}$ Mary replied, however, that no claim to unjust spoliation could be made by one who had come into possession of a thing by fraud. Since Hell only had gained possession of humankind through the lies of the devil in the Garden of Eden, it could not claim rightful possession now. On this point, Christ sided with Mary and denied to the demon his claim for restitution.

Undaunted, the demon changed tactics. Abandoning his claim for restitution, he strode forward, presented the Bible, and began to read from Genesis concerning Adam's disobedience in the garden. The demon argued that the violation of divine command accomplished by Adam and Eve was imputable to the entire human race. To this, Mary countered by claiming that Adam and Eve sinned at the urging of the serpent by whom Eve was deceived into disobeying God. As a party complicit in the crime, argued Mary, Hell could not now bring an accusation against another for the same crime. But the procurator had a response ready. Relying on the logic of the inquisitorial procedures that canonists had developed in the early thirteenth century, the demon explained that when a delictum is perpetrated notoriously, a judge should proceed and punish it even if there is no accuser. Hence, the obligation to proceed against humankind fell to Christ as judge, regardless of whether the devil was complicit in original sin (and therefore unable to bring an accusation) or not.

This argument struck a cord with Mary. Her response was dramatic. Fearing that the judge would find against humankind, Mary stopped relying on citations to Roman-canon law. Instead, following "the fragility of the womanly sex," Mary "exploded into tears, knelt, and cut her vestments open at the breast." ${ }^{60}$ Addressing her son, she sobbed "My blessed son, there is the one who rejected you, stoned you, had you tied to a column, and hung on a cross like a thief. He implores your noble office. I am your most dear mother that carried you for nine months and piously nourished you with milk from these breasts." If you find for the demon, she wept, "delete me from your book of life." ${ }^{61}$ This vignette, in which the advocate was

59. Fol. 192r.

60. Fol. 193r.

61. Ibid. 
reduced to a weeping woman, was a prime reason modern scholars dismissed the text. Indeed, how could one not agree with the demon when he remarked to Christ, "I say to you that flesh and blood, not celestial justice, have been revealed by the Son." 62

From the perspective of medieval canonists and theologians, the demon's remark betrayed ignorance of an important attribute of Mary's tears. For both theology and canon law placed heavy stress on the spiritual efficacy of tears. Tears were not merely an attribute of the body in the medieval period; they were also a profound and necessary medium for intercession, spiritual renewal, and justification. ${ }^{63}$

But there appears to be more to Mary's action than mere tears. In a curious bit of testimony given at the canonization process of Yves Hélory in Brittany in the 1330s, we find the following. A certain young man (also named Yves) was freed from demonic possession by the saint. The young man's demonic possession had first occurred when his mother cursed him by "falling to her knees and extracting her breasts from her garment, saying: 'I give to you my curse with these breasts which you sucked and my womb in which I carried you and by whatever rights [juris] I have in you and am able to have in you ... all of it I give over and concede to the devil." ${ }^{64}$ The mother's curse contains a nearly exact replication of the gestures attributed to Mary in the Processus Sathanae, but here the scene is inverted. Rather then asking to be deleted from the book of life, Yves' mother explicitly cedes her rights, as jura, to the devil. The invocation and exposure of nursing breasts and a carrying womb remains the same, suggesting something of an archetype for pleading or cursing. It is a gesture of possession and dispossession, and as such it is an act of transfering, or threatening to transfer, rights. Whereas the mother of Yves dispossessed him

62. Fol. $193 \mathrm{v}$.

63. On the theological aspects of tears in the middle ages, see Piroska Nagy, Le don des larmes au Moyen Âge (Paris, 2000); on the legal aspects, see William J. Courtenay and Karl B. Shoemaker, "The Tears of Nicholas: Simony and Perjury by a Parisian Master of Theology in the Fourteenth Century", Speculum (2008) 83: 603-628.

64. Monuments originaux de l'histoire de Saint Yves, eds. A. de la Borderie, J. Daniel, R.P. Perquis, and D. Tempier (Saint Brieuc: L. Prud'homme, 1887), p. 419-420. This scene is discussed in Alain Boureau, Satan hérétique, op. cit., chapter 5. 
and abandoned him to the devil, Mary restated her belonging to humankind, willing even to join us in eternal damnation should the devil prevail. Whereas the mother of Yves willingly gave up her rights, Mary recalled her son to the maternal relationship that bound them. Whereas the mother of Yves gave up her rights in anger and despair, Mary claimed her rights in Christian faith. More than simply the tearful expression of an overwrought woman, Mary's gesture in the trial was deeply bound up in fourteenthcentury understandings of the rights of motherhood. In this way, Mary's plea was not extralegal.

Mary's plea was effective. Moved by her pious tears, Christ denied the petition of the demon and refused to hear criminal charges against humankind. As a formal matter, the trial was still not over, though it is clear that everything from this point onward had tipped in Mary's favor. The demon insisted on a distribution of souls between Mary and Hell. He was willing to allow her to take the good souls and to content himself with the bad souls. It was a division the demon anticipated would be beneficial to Hell. But Mary was ever vigilant, and reminded Christ in explicitly theological terms that he had already suffered punishment on behalf of humankind. What the demon sought was already a res judicata. There was nothing to litigate. The demon was expelled from the heavenly court, and Mary was showered with praise from the choir of angels.

It is clear that the Processus Sathanae is an expression of Marian theology, set in juridic terms. But it is also an account of human salvation framed by the processes of fourteenth-century Romancanon law. The Processus Sathanae insisted that the theology of Christian redemption could be coherently presented through the processes of canon law, and that the devil's one-sided understanding of law was the result of an engagement with law that was blind to its spiritual content and purpose. The Processus Sathanae addressed human salvation in a manner that also implicated the relationship between Christ (and his vicar on earth, the pope) and the law, framing the matter within the theological and jurisprudential issues of the late medieval world. At bottom, it all depended on a world of seamless intelligibility that linked spiritual truth and legal processes, 
whether human or divine. It also depended on a world that was granted reason and historical purpose by a presumed loving deity susceptible to being moved by tears and capable of dissolving rules of law in favor of a higher justice, one which resulted in the salvation of humankind. Whatever squabbles divided canonists and theologians, the devil's lawsuit provided a medium by which the troublesome relationship between divine justice and divine power was given one explanation in the fourteenth century.

kbshoemaker@wisc.edu 